\title{
Bark beetle associated trematurid mites (Acari: Uropodina: Trematuridae) from Asian Russia with description of a new species
}

\author{
JENÖ KONTSCHÁN ${ }^{1 *}$, GÁBOR SZŐCS ${ }^{1}$, BALÁZS KISS ${ }^{1} \&$ ALEXANDER A. KHAUSTOV ${ }^{2}$ \\ ${ }^{1}$ Plant Protection Institute, Centre for Agricultural Researches, Hungarian Academy of Sciences, H-1025, Budapest, PO \\ Box. 102. Hungary. \\ ${ }^{2}$ Tyumen State University, Tyumen, Semakova 10, 625003 Russia. \\ Corresponding author:kontschan.jeno@agrar.mta.hu
}

\begin{abstract}
A new Oodinychus Berlese, 1917 species, O. scolytana sp. nov., was discovered and described from the galleries of bark beetles Polygraphus proximus Blandford from two different parts of Asian Russia. New associations are given for the trematurid mites and bark beetle species. Three bark beetle associated species from the Trichouropoda ovalis-group are moved into the genus Oodinychus as O. hirsuta (Hirschmann, 1972) comb. nov., O. rafalski (Wiśniewski \& Hirschmann, 1984) comb. nov. and O. wilkinsoni (Hirschmann \&Wiśniewski, 1986) comb. nov. Also, Oodinychus egypticus Abo-Shnaf, El-Bishlawy \& Allam, 2018 is transferred to the genus Nenteria Oudemans, 1915.
\end{abstract}

Key words: Mesostigmata, systematics, association with bark beetles, Scolytinae, Eastern Palaearctic

\section{Introduction}

The mite association with bark beetles (Coleoptera: Curculionidae: Scolytinae) is an intensively studied aspect of acarology. Until today numerous reports have been presented about this topic world-wide (e.g. Moser et al. 2010; Pentinnen et al. 2013; Khaustov et al. 2016, 2018, 2018; Lieutier et al. 2016; Wirth et al. 2016; Zach et al. 2016; Vissa et al. 2019).

Uropodina is a specific group within the bark beetle associated mites; several species occur in the galleries, but numerous others were usually collected as phoretic deutonymphs on the body of the beetles. Trematuridae is a distinct family within the Uropodina with numerous unique character states, like the shape of the corniculi, tritosternum, chelicerae, presence of pedofossae and sculptural pattern on the body (Kontschán 2019). Until today, more than 100 trematurid species have been described from different regions of the world (Wiśniewski \& Hirschmann 1993). The majority of these species occur in soil, moss and leaf litter, but some species live in association with several beetle groups, like bark beetles. We have very few information about the biology of the trematurids, maybe these species feed on fungus.

Our present paper contains the first records of the bark beetle associated Uropodina from the Asian part of Russia.

\section{Material and Methods}

The galleries of bark beetles were cut by axe or knife with pieces of the barks in the forests and placed into plastic boxes, then the samples transported to the laboratory and all mites collected from the galleries under stereomicroscope Discovery V8. 
The specimens investigated in this study were cleared in lactic acid, the drawings made with the aid of a camera lucida on a Leica 1000 compound microscope, the photo taken with Huawei P30 Lite mobile attached to the microscope. All specimens of the new species are preserved in ethanol and deposited in the Hungarian Natural History Museum (HNHM), Budapest, Hungary; Natural History Museum, Geneva (NHMG), Schwitzerland and Tyumen State University (TSU), Russia. Abbreviations: $s t=$ sternal setae, $h=$ hypostomal setae, $a d=$ adanal setae, $l f=$ lyriform fissure, $p=$ pore, $s=$ spine-like organ. The measurements and the scales in the figures are given in micrometers $(\mu \mathrm{m})$.

\section{Results}

List of the found species

\section{Trichouropoda polytricha (Vitzthum, 1923)}

Uropoda polytricha Vitzthum, 1923, p. 149, Figures 48, 49.

Uropoda polytricha: Vitzthum 1926.

Pseuduropoda polytricha: Vitzthum 1943.

Trichouropoda polytricha: Hirschmann \& Zirngiebl-Nicol 1961, Moser \& Bogenschütz 1984, Moser et al. 1989; Karg 1989, Takov et al. 2009; Kršlak et al. 2010; Feketeová 2011; Gwiazdowicz et al. 2011; Gwiazdowicz \& Gutowski 2012; Vrabec et al. 2012, Chaires-Grijalva et al. 2013, Fernández et al. 2013, Knee et al. 2013, Penttinen et al. 2013, Čejka \& Holuša 2014, Khaustov et al. 2016, Khaustov et al. 2018.

\section{Material examined}

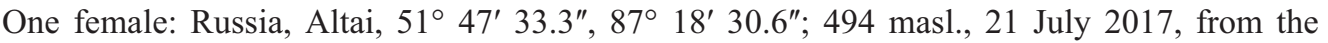
galleries of Ips sexdentatus Boerner, under the bark of Pinus silvestris Linnaeus, coll. A.A. Khaustov.

Remarks

This species was known from the Holarctic and collected from the galleries of bark beetles, like Scolytidae (Wiśniewski \& Hirschmann 1993), Ips typographus (Linnaeus) (Moser \& Bogenschütz 1984; Moser et al. 1989; Takov et al. 2009; Feketeová 2011; Gwiazdowicz et al. 2011; Gwiazdowicz \& Gutowski 2012; Vrabec et al. 2012; Fernández et al. 2013; Knee et al. 2013; Penttinen et al. 2013; Čejka \& Holuša 2014; Khaustov et al. 2018), Ips sexdentatus Boerner (Fernández et al. 2013), Hylastes cunicularius Erichson (Kršlak et al. 2010), Dryocoetes autographus Ratzeburg, Ips amitinus Eichhof, I. cembrae (Heer), I. hauseri (Reitter), I. pilifrons utahensis Wood, I. woodi Thatcher, I. montanus Eichhof, I. perturbatus (Eichhof), I. hunteri Swaine, I. borealis Swaine, Pityogenes chalcographus Linnaeus (Khaustov et al. 2016; Knee et al. 2013), and Dendroctonus rhizophagus Thomas \& Bright (Chaires-Grijalva et al. 2013).

\section{Trichouropoda structura Hirschmann \& Zirngiebl-Nicol, 1961}

Trichouropoda structura Hirschmann \& Zirngiebl-Nicol 1961, pp. 2 and 33, Figures 1: 22 and 7d.

Trichouropoda structura: Hirschmann \& Wiśniewski 1987, Karg 1989, Kiełczewski \& Wiśniewski 1983, Khaustov et al. 2018.

\section{Material examined}

One female, one male, seven deutonymphs: Russia, Sakhalin Island, 46 51' 92.2", $142^{\circ} 52^{\prime}$ 42.7"; 302 masl., 14 August 2017, from the galleries of Ips subelognatus Motschulsky under the bark of Larix curilensis Mayr, coll. A.A. Khaustov. Two females: Russia, Altai, $51^{\circ} 57^{\prime} 14.9^{\prime \prime}, 84^{\circ} 51^{\prime}$ 
50.2"; 738 masl., 23 July 2017, from the galleries of Polygraphus proximus Branford, under the bark of Abies sibirica Willson, coll. A.A. Khaustov.

Remarks

This species is known from the galleries of bark beetles, like Scolytidae in Wiśniewski \& Hirschmann (1993), Pityogenes chalcographus Linnaeus (Kiełczewski \& Wiśniewski 1983) and Ips typographus (Linnaeus) (Khaustov et al. 2018).

\section{Oodinychus scolytana sp. nov.}

(Figures 1-31)

Diagnosis

Setae $j 1$ longer than other dorsal setae and marginally serrate. Two pairs of serrate setae situated on caudal area of dorsal shield, and other two pairs of marginally serrate setae on caudal part of marginal shield. Genital shield of female bearing 4-8 oval pits, and some oval pits situated between metapodal lines. Setae $s t 2 \mathrm{Y}$-shaped in males.

\section{Type material}

Holotype. Female: Altai, 623 masl., in the galleries of Polygraphus proximus Blandford, under the bark of Abies sibirica Willson, 52 $02^{\prime} 13.4^{\prime \prime}, 86^{\circ} 33^{\prime} 04.9^{\prime \prime}, 21$ July 2017, coll. A.A. Khaustov. (NHMG). Paratypes. Six females and two males: collection date same as in holotype (two females and one male in HNHM and four females and one male in TSU). Other paratypes. Five females and six males: Altai, 738 masl., in the galleries of Polygraphus proximus Blandford, under the bark of

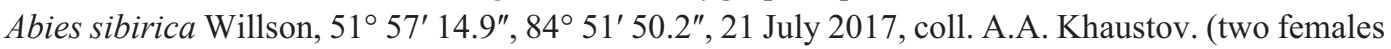
and two males in NHMG, one female and two males in HNHM, two females and two males in TSU).

\section{Description}

Female ( $\mathrm{n}=12)$

Length of idiosoma 810-835, width at level of coxae IV 550-580. Idiosoma oval-shaped, posterior margin rounded, color reddish-brown, whole idiosoma strongly sclerotized.

Dorsal idiosoma (Figure 1). Marginal and dorsal shields completely separated. Surface of marginal shield smooth in anterior region and scalloped on caudal part. Majority of setae on marginal shield smooth and needle-like ( $c$ 22-25 long), except two pairs of serrate setae ( $c a 30-35$ long) on posterior area. Dorsal shield oval-shaped, neotrichous, bearing smooth and needle-like setae ( $\mathrm{ca} 22-$ 26 long). Setae $j 1$ longer ( $c a$ 27-29 long) than other dorsal setae and marginally serrate (Figure 2). Setae on posterior part of dorsal shield associated with oval pits $(25 \times 30)$ (Figure 3$)$, setae on anterior area without oval pits. Two pairs of marginally serrate setae ( $c a 35-40$ long) visible on caudal area of dorsal shield (Figure 4). Four pairs of lyrifissures and numerous spine-like organs placed on dorsal shield.

Ventral idiosoma (Figure 5). Sternal setae (st1-5) short ( ca 20-26 long), smooth and needlelike. Setae $s t 1$ situated at level of anterior margin of coxae II, $s t 2$ at mid-level of coxae II, st 3 at posterior level of coxae II, st 4 at anterior level of coxae IV, st 5 close to basal margin of genital shield and associated with oval pits. Surface of sternal shield with some oval pits. One pair of lyriform fissures situated near st 1 , two pairs close to $s t 5$, two additional pairs close to anterior and posterior areas of the metapodal lines, and other two pairs anterior to anal opening. Numerous other sensory organs situated on ventral idiosoma. Spine-like organs visible close to stl and st4, posterior to metapodal line and anterior to anal opening. Pore-like organs situated anterior to and anterolaterad 
anal opening, one pair situated anterior and one pair posterior to metapodal line, and one pair on pedofossae IV. Ventral shield with 5-6 pairs of needle-like setae ( $c a$ 28-32 long), associated with oval pits and two pairs of needle like setae ( $\mathrm{ca} 30-34 \mathrm{long}$ ), without oval pits anterior to anal opening, with 12-13 smooth and needle-like setae on margin of ventral shield and 13-15 needle-like setae ( $c$ a 30-33 long) on margins of the ventral idiosoma anterior to metapodal line. Ventral region of opisthogastric surface covered by some oval pits anterior and lateral to anal opening. Anal opening longer than wide (2.2:1), with two pairs of smooth and needle-like adanal setae (ca 32-34 long), and one smooth and needle-like postanal seta ( $c a$ 19-23 long) (Figures 12-13). Pore-like structures situated close to short ventral setae and posterior to pedofossae IV. Metapodal line present. Genital shield $c a$ 240-250 long and $c a$ 115-120 wide, situated between coxae II-IV, with peaked anterior margin and shield surface with some oval pits. Number of pits very variable in different paratypes (Figures 6-11). Prestigmatid part of peritremes long, with two bends, poststigmatid part short and straight (Figure 14), stigmata situated between coxae II and III. Pedofossae deep and with smooth surface, separated furrows for tarsi IV present with pores. Tritosternum with narrow base, tritosternal lacinia marginally serrate and apically divided into one short and two long spine-like branches (Figure 15).

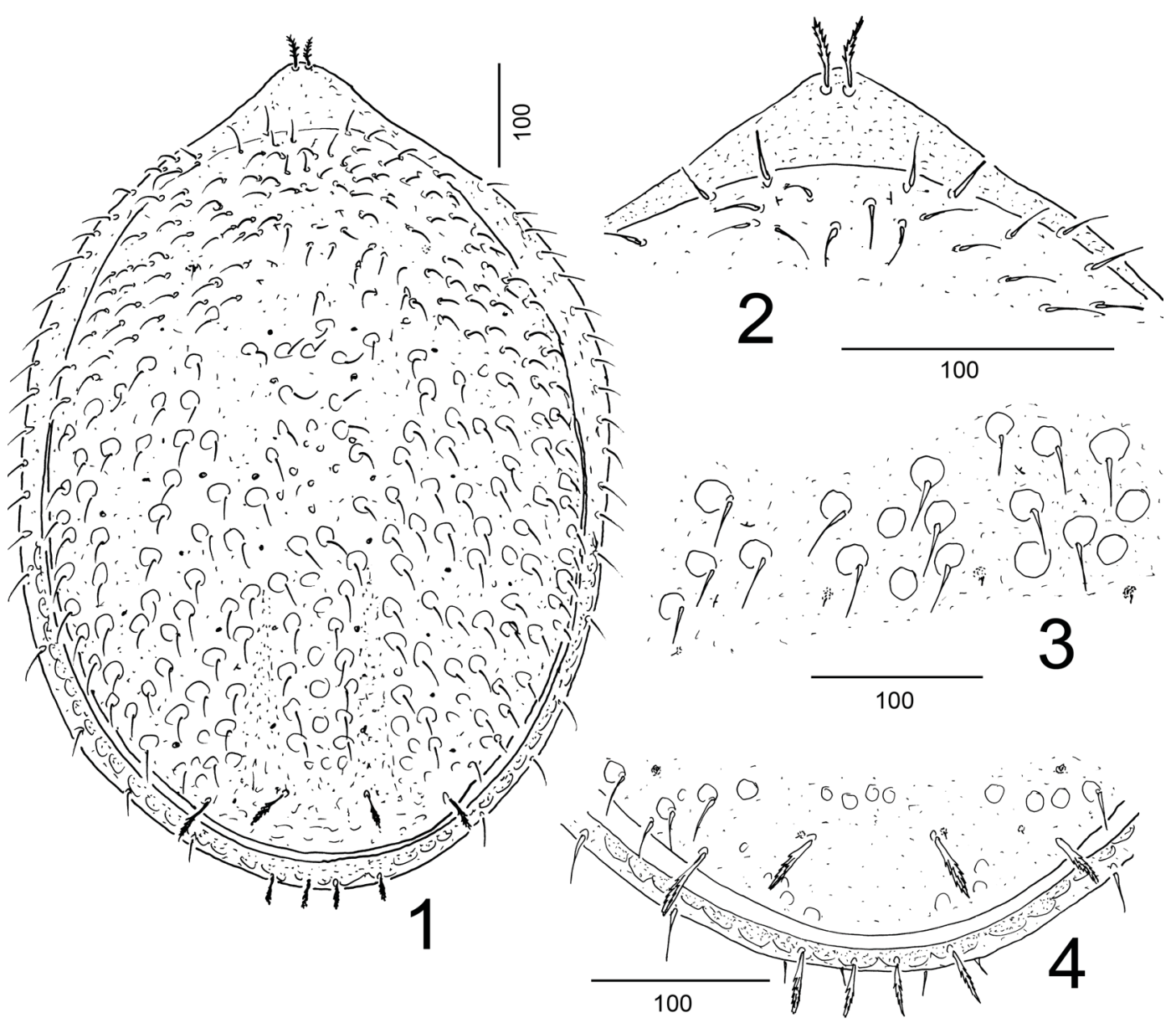

FIGURES 1-4. Oodinychus scolytana sp. nov., female, holotype. 1. Dorsal view of idiosoma; 2. Apical part of idiosoma; 3. Sculptural pattern and dorsal setae; 4. Caudal part of dorsal idiosoma. 

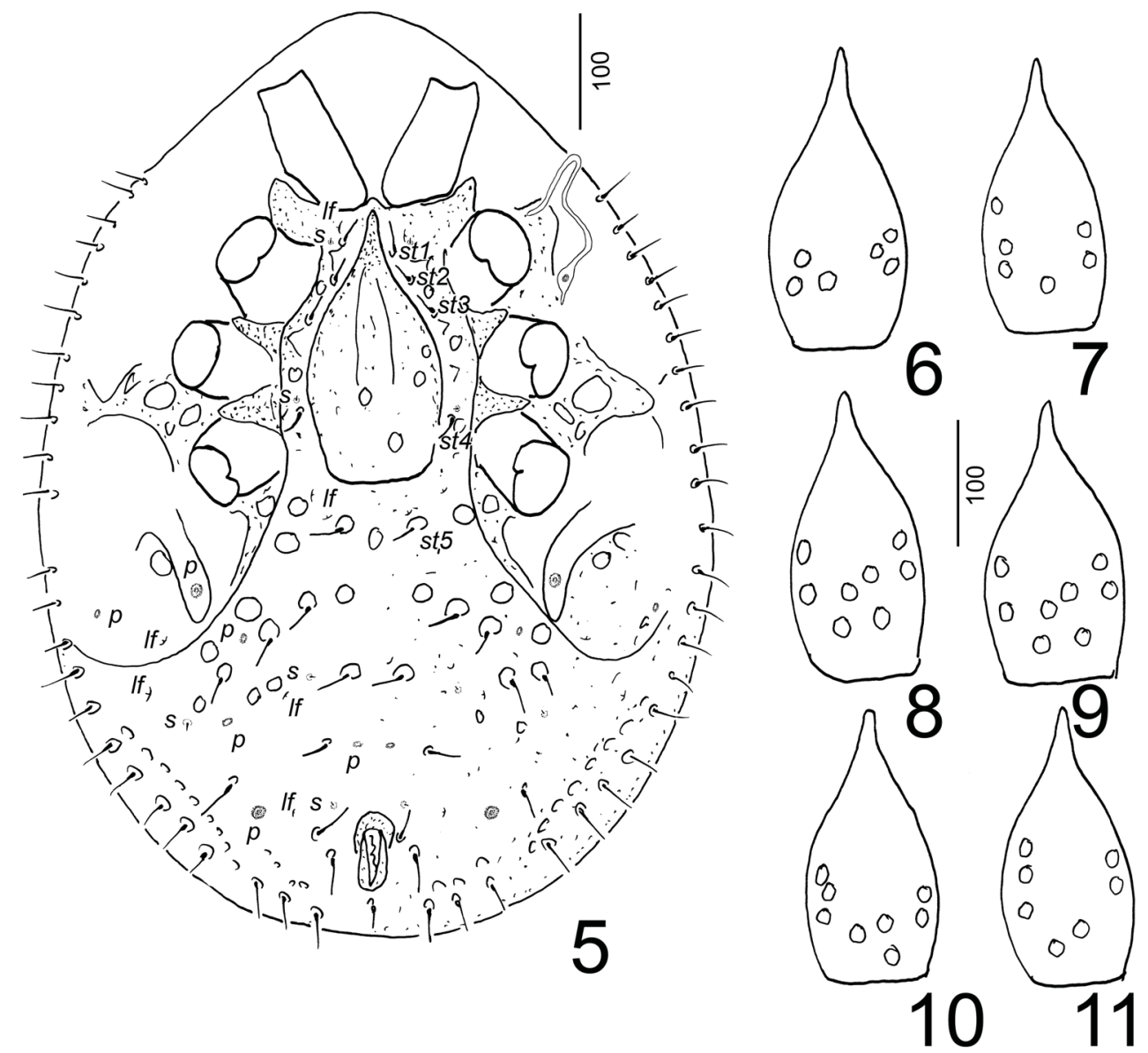

FIGURES 5-11. Oodinychus scolytana sp. nov., female, holotype; 5. Ventral view of idiosoma; 6-11. Genital shields of paratypes.

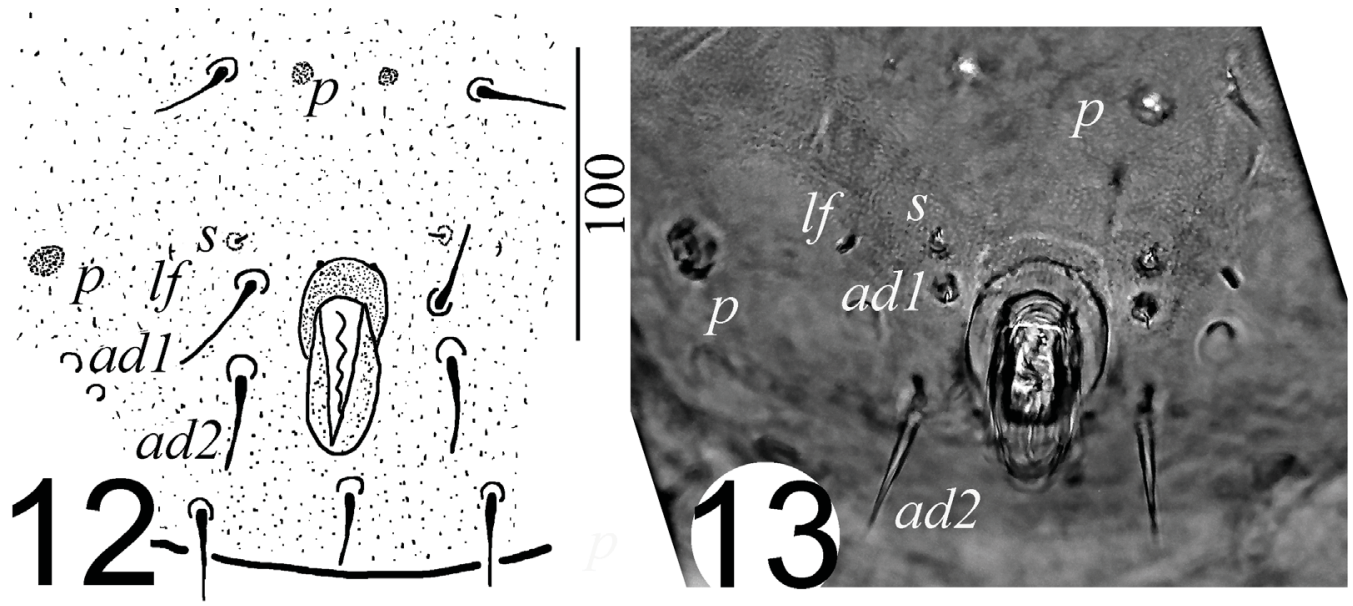

FIGURES 12-13. Oodinychus scolytana sp. nov., female, holotype. 12. Anal region; 13. Anal region in microscopic photo. 


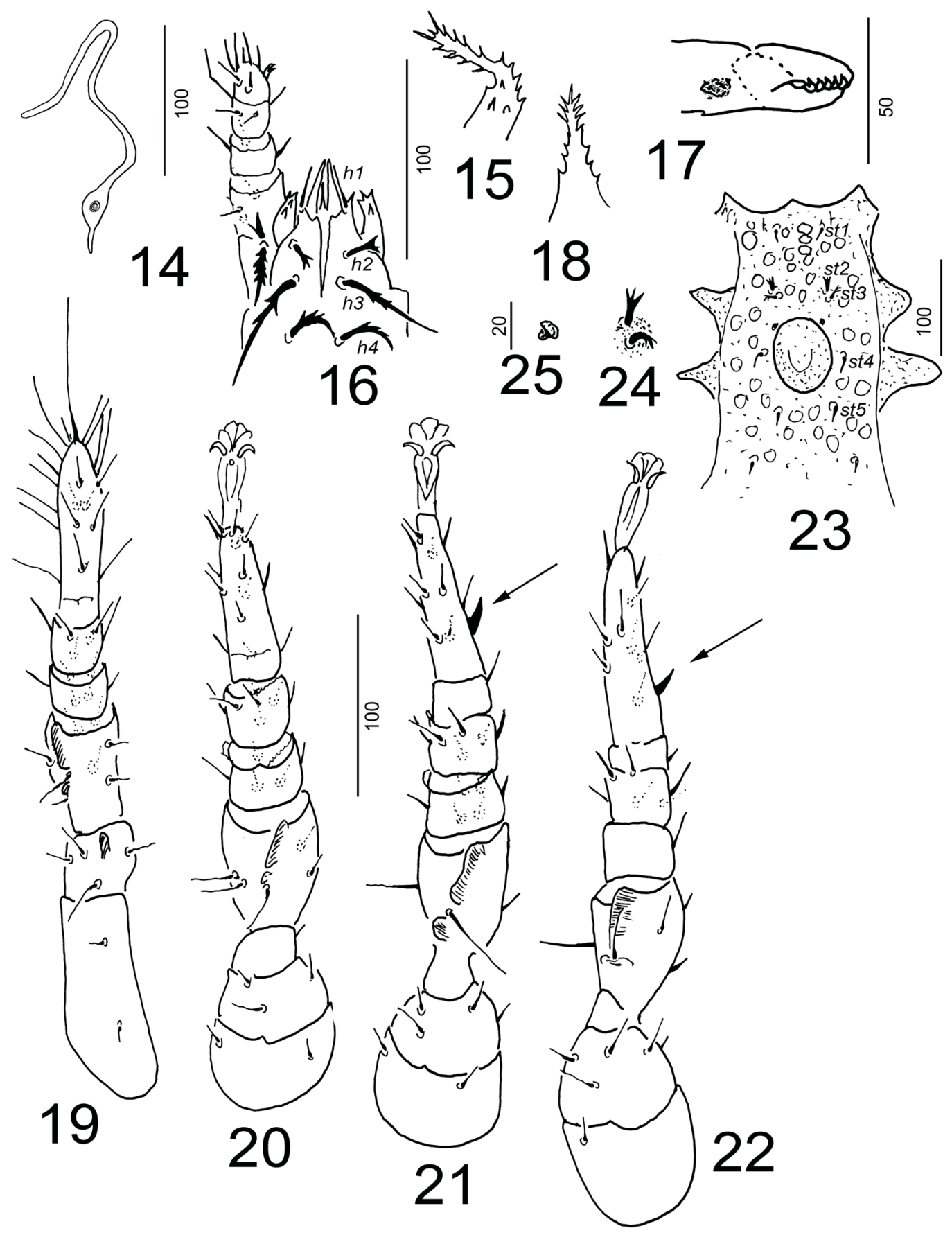

FIGURES 14-25. Oodinychus scolytana sp. nov., female, holotype. 14. Peritreme; 15. Tritosternum; 16. Ventral view of gnathosoma and palp; 17. Chelicera; 18. Epistome; 19. Leg I in ventral view; 20. Leg II in ventral view; 21. Leg III in ventral view; 22. Leg IV in ventral view (arrows show the spine-like setae); 23. Intercoxal area of male paratype; 24 . Setae $s t 2$ and $s t 3 ; 25$. Pore-like sensory organ close to anterior margin of male genital opening. 

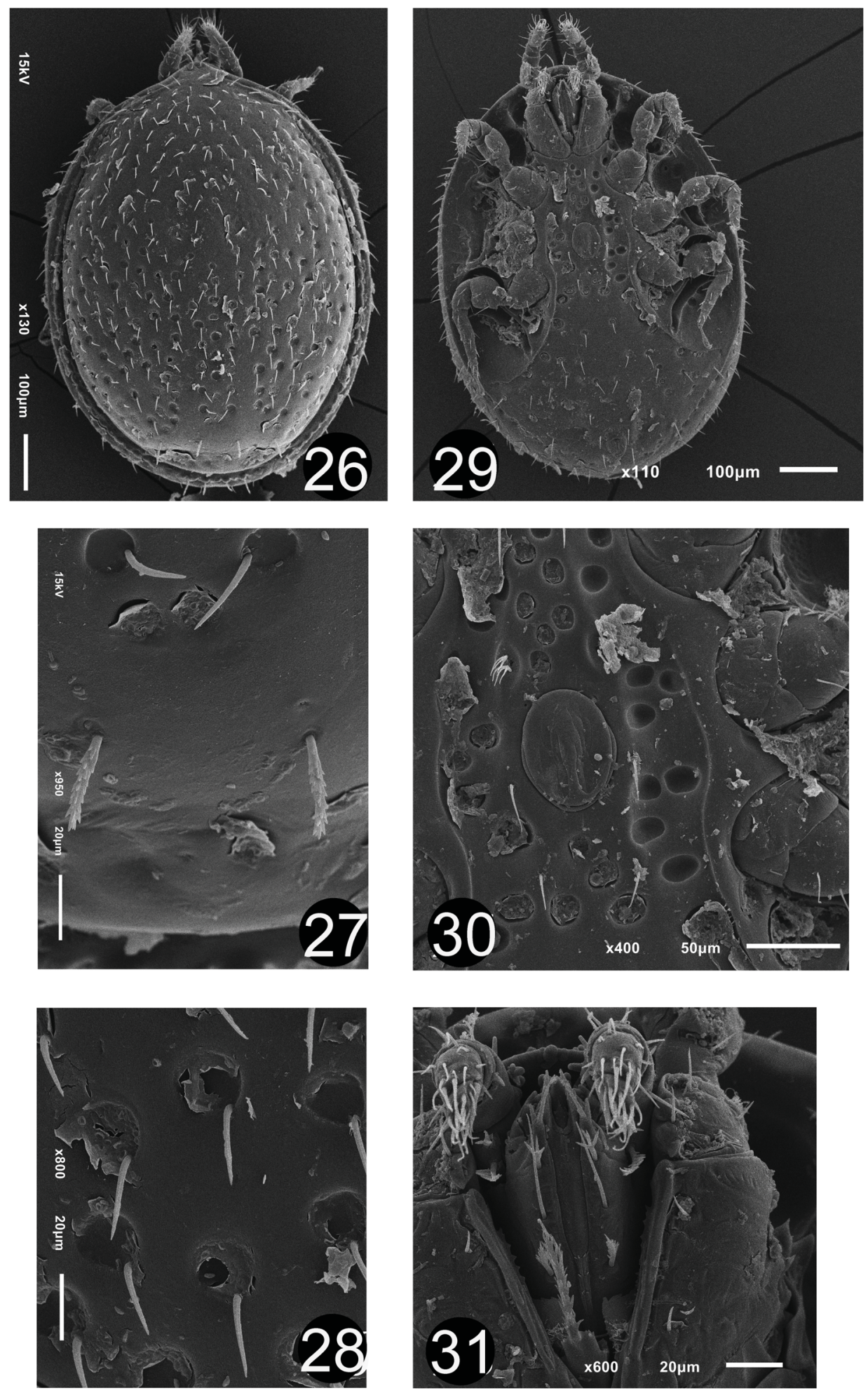

FIGURES 26-31. SEM micrographs of Oodinychus scolytana sp. nov., male, paratype. 26. Dorsal view of idiosoma; 27. Setae on caudal area of dorsal shield; 28. Pits and setae on dorsal shield; 29. Ventral view of idiosoma; 30. Intercoxal area of male; 31 . Ventral view of gnathosoma and tritosternum. 
Gnathosoma (Figure 16). Corniculi horn-like, with three lateral teeth, internal malae smooth, narrow, shorter than corniculi. Hypostomal setae $h 1$ smooth and needle-like ( $c a$ 20-22 long), $h 2$ apically trifurcated ( $c a$ 13-16 long), $h 3$ ( $c$ a 56-62 long) and $h 4$ ( $c a$ 30-34 long) long and marginally serrate. Movable digit of chelicerae as long as fixed digit, both digits bearing numerous small teeth, internal sclerotized node present (Figure 17). Margin of epistome serrate (Figure 18). Palps bearing smooth setae, except those on palp trochanter, with a long serrate and a short bifurcated ventral seta; palp apotele bifurcate (Figure 16).

Legs (Figures 19-22). Length of legs: I 355-360, II 320-330, III 350-365, IV 375-380. Legs I without ambulacral claws (Figure 19), other claws on legs II-IV large. All legs with smooth and needle-like setae, except one robust dorsal seta on tarsi III-IV. Femora of legs I-IV with large lateral flaps. Legs chaetotaxy as mentioned in Evans (1972).

\section{Male $(\mathbf{n}=8)$}

Length of idiosoma 800-840, width 530-580.

Dorsal idiosoma (Figures 26-28). As in female.

Ventral idiosoma (Figures 23, 29). Surface of sternal shield with numerous oval pits. Three pairs of smooth, short ( $c$ a 10-16 long) and needle-like and two pairs of bifurcated sternal setae present. Setae st 1 placed near to anterior margin of sternal shield, st 2 trifurcated and situated at level of posterior margin of coxae II, st 3 similar in shape and length to st 2 and situated close to st2 (Figure 24), st4 situated lateral to genital shield, st 5 at level of posterior margin of genital shield. One pair of lyriform fissures present close to st1, one pair close to st5. One pair of lyrifissures present close to st 1 and one pair of pores present close to anterior margin of genital shield (Figures 25, 30). Position and shape of ventral setae and ornamentation of ventral shield as in female. Genital shield oval-shaped ( $c a$ 76-80 long and $c a$ 55-59 wide), without sculptural pattern, and situated between coxae III.

Gnathosoma (Figure 31). As in female, except smooth setae $h 3$.

Nymphs and larvae unknown.

Etymology. The name of the new species refers to the association with bark beetles (Scolytinae).

\section{Discussion}

The genus Oodinychus, or the Trichouropoda ovalis species group in Hirschmann's Gangsystems, contains more than 50 species from all over the world (Wiśniewski \& Hirschmann 1993). Currently, a new diagnosis of the genus Oodinychus together with the description of a new species, Oodinychus egypticus Abo-Shnaf, El-Bishlawy \& Allam, 2018, and a key to nine species of the genus has been presented by Abo-Shnaf et al. (2018). The newly described species has paralaciniae on the gnathosoma (see Figure 1F in Abo-Shnaf et al. (2018)), which is a specific character of the genus Nenteria Oudemans, 1915. So, this species does not belong to the genus Oodinychus and herein is transferred to the genus Nenteria, as Nenetria egypticus Abo-Shnaf, El-Bishlawy \& Allam, 2018 comb. nov. Based on the latter mentioned reason, the diagnosis of the genus Oodinychus presented in Abo-Shnaf et al. (2018) is also very questionable and does not match with more than 50 described species under Oodinychus.

More than 20 species of genus Oodinychus have been reported in association with beetles, and four species were collected together with bark beetles (Wiśniewski \& Hirschmann 1993; Khaustov et al. 2018). Three of these four species were placed in the large genus Trichouropoda sensu lato (Wiśniewski \& Hirschmann 1993), while Oodinychus karawaiewi (Berlese, 1904) was previously 
moved (see Wiśniewski \& Hirschmann 1993). However, in our opinion based on the dorsal and ventral sculptural pattern, the shape of genital shield and the presence of the two pairs of pilose setae on caudal part of dorsal shield, these other three species need to be transferred to the genus Oodinychus too, as O. hirsuta (Hirschmann, 1972) comb. nov.; O. rafalski (Wiśniewski \& Hirschmann, 1984) comb. nov. and O. wilkinsoni (Hirschmann \& Wiśniewski, 1986) comb. nov. The most important differences between these five bark-beetles associated Oodinychus species are presented in Table 1.

TABLE 1. Distinguishing characters among the bark-beetle associated Oodinychus species.

\begin{tabular}{|c|c|c|c|c|c|}
\hline & O. karawaiewi & O. hirsuta & O. rafalskii & O. wilkinsoni & O. scolitana \\
\hline $\begin{array}{l}\text { Pits on dorsal- and } \\
\text { ventral idiosoma }\end{array}$ & irregular & oval & oval & oval & oval \\
\hline $\begin{array}{l}\text { Position of pits on } \\
\text { female genital shield }\end{array}$ & $\begin{array}{l}\text { several and situated on all } \\
\text { area of genital shield }\end{array}$ & without pits & $\begin{array}{l}\text { few and situated on } \\
\text { all area of genital } \\
\text { shield }\end{array}$ & $\begin{array}{l}\text { few and situated } \\
\text { close to basal } \\
\text { margin }\end{array}$ & $\begin{array}{l}\text { few and situated close } \\
\text { to basal margin }\end{array}$ \\
\hline $\begin{array}{l}\text { Shape of female genital } \\
\text { shield }\end{array}$ & $\begin{array}{l}1 \text { scutiform with apical } \\
\text { process }\end{array}$ & $\begin{array}{l}\text { scutiform with } \\
\text { apical process }\end{array}$ & $\begin{array}{l}\text { scutiform with } \\
\text { apical process }\end{array}$ & $\begin{array}{l}\text { oval, with a spine } \\
\text { like apical } \\
\text { process }\end{array}$ & $\begin{array}{l}\text { scutiform with apical } \\
\text { process }\end{array}$ \\
\hline Genital shield of male & without court & without court & without court & with court & without court \\
\hline Setae $s t 3$ in females & longer than $s t 1$ and st 2 & $\begin{array}{l}\text { longer than st } 1 \text { and } \\
\text { st } 2\end{array}$ & $\begin{array}{l}\text { longer than } s t 1 \text { and } \\
\text { as long as } s t 2\end{array}$ & $\begin{array}{l}\text { longer than } s t 1 \\
\text { and } s t 2\end{array}$ & as long as $s t 1$ and $s t 2$ \\
\hline Setae $s t 2$ in males & smooth & smoothi & pilose & pilose & bifurcate \\
\hline Setae $h 3$ & pilose & pilose & pilose & smooth & serrate \\
\hline $\begin{array}{l}\text { Surface of margin of } \\
\text { ventral idiosoma }\end{array}$ & reticulate & reticulate & smooth & reticulate & smooth \\
\hline $\begin{array}{l}\text { Setae on caudal part of } \\
\text { marginal shield }\end{array}$ & $\begin{array}{l}\text { with two pairs of } \\
\text { marginally serrate setae }\end{array}$ & $\begin{array}{l}\text { with two pairs of } \\
\text { marginally serrate } \\
\text { setae }\end{array}$ & needle-like & $\begin{array}{l}\text { with two pairs of } \\
\text { marginally } \\
\text { serrate setae }\end{array}$ & $\begin{array}{l}\text { f with two pairs of } \\
\text { marginally serrate } \\
\text { setae }\end{array}$ \\
\hline
\end{tabular}

The widely distributed species of the genus Oodinychus, O. ovalis (C.L. Koch, 1839), differs in the number and position of the oval pits on female genital shield from the new species. The whole surface of the female genital shield in $O$. ovalis is covered with numerous of pits, but the female genital shield in the new species has fewer (usually 6-8) oval pits which are scattered in $2 / 3$ posterior region of the shield. On the other hand, reticulate sculptural pattern is presented lateral to outer margins of pedofossae on ventral idiosoma of $O$. ovalis, contrary with the new one, where this character is absent. Oodinychus ovalis seems to be polymorphic on molecular point of view in the studied polish specimens (although only one gene was investigated by Błoszyk et al. (2019)), but based on the investigated specimens occurring in several European countries, e.g. Switzerland, Slovenia, Hungary, Romania and the countries of the Balkan Peninsula, the morphological aspects of the species do not show notable intraspecific variations (Kontschán 2009, 2011, 2013, 2014)).

The new species differs from the other and non-bark-beetle associated species of Oodinychus (or the Trichouropoda ovalis-group) in the following character combination: number of pits on the female genital shield is few, reticulate sculptural pattern lateral to outer margins of pedofossae on ventral idiosoma absent and the presence of two pairs of serrate setae on caudal part of the marginal shield. These characters are not visible together in the previously described species of the genus Oodinychus or the Trichouropoda ovalis-group. 


\section{Acknowledgement}

The authors thank Dr. M. Yu. Mandelshtam (Centre for Bioinformatics and Genome Research, Saint-Petersburg S.M. Kirov State Forest Technical University, Russia) for the identification of the bark beetles and A. Gubin (Tyumen State University, Russia) for preparation of SEM images. The authors also thank to Dr. V.A. Trach (Odessa I. I. Mechnikov National University, Odessa, Ukraine) and Mr. R.V. Latyntsev (Tyumen State University, Tyumen, Russia) for the help during collecting of samples. This study was in part supported by the research grant NKFIH K124278. We are very grateful to Dr. Jason Dunlop for the linguistic correction of the manuscript.

\section{References}

Abo-Shnaf, R.I.A., El-Bishlawy, S.M.O. \& Allam, S.F.M. (2018) Description of a new species of Oodinychus (Acari: Uropodina: Trematuridae) from Egypt, with a key to the species. Acarologia, 58(3), 546-556. http://doi.org/ 10.24349/acarologia/2018425

Berlese, A. (1904) Acari nuovi. Manipulus II. Redia, 1, 258-280.

Berlese, A. (1917) Intorno agli Uropodidae. Redia, 13, 7-16.

Błoszyk, J., Buczkowska, K., Bobowicz, A. M., Bączkiewicz, A., Adamski, Z. \& Napiearała, A. (2019) Are polymorphic species of Uropodina (Acari: Mesostigmata) more successful evolutionarily? - A case study of closely related species from the genus Oodinychus Berlese, 1917 based on DNA sequences. Systematic and Applied Acarology, 24(5), 866-881. http://doi.org/10.11158/saa.24.5.10

Čejka, M. \& Holuša, J. (2014) Phoretic mites in uniand bivoltine populations of Ips typographus: a 1-year case study. Turkish Journal of Zoology, 38, 569-574. http://doi.org/10.3906/zoo-1309-20

Chaires-Grijalva, M.P., Estrada-Venegas, E.G., Equihua-Martinez, A., Moser, J.C., Sanchez-Martinez, G. \& Vazquez-Rojas, I.M. (2013) Mesostigmados (Acari: Mesostigmata) asociados con Dendroctonus rhizophagus de Chihuahua, Mexico. Revista Mexicana de Biodiversidad, 84, 1235-1242. http://doi.org/ 10.7550/rmb.35723

Evans, G.O. (1972) Leg chaetotaxy and classification of the Uropodina (Acari: Mesostigmata). Journal of Zoology, London, 167, 193-206.

Feketeová, Z. (2011) Význam uropodných roztočov (Acari: Uropodina) v ekológii lykožrúta smrekového (Ips typographus). Entomofauna carpathica, 23, 11-19.

Fernández, M., Julio, D. \& Moraza, M.L. (2013) Acarofauna associated with Ips sexdentatus in northwest Spain. Scandinavian Journal of Forest Research, 28, 358-362. http://doi.org/10.1080/02827581.2012.745897

Gwiazdowicz, D.J. \& Gutowski, J.M. (2012) Records of phoretic mesostigmatid mites (Acari: Mesostigmata) on beetles (Coleoptera: Carabidae, Cerambycidae, Elateridae, Erotylidae, Scolytinae) in the Białowieża Primeval Forest. Polskie pismo entomologiczne, 81, 305-310. http://doi.org/10.2478/v10200-012-0010-2

Gwiazdowicz, D.J., Kamczyc, J. \& Błoszyk, J. (2011) The diversity of phoretic Mesostigmata on Ips typographus (Coleoptera: Scolytinae) caught in the Karkonosze forest. European Journal of Entomology, 108, 489-491

Hirschmann, W. (1972) Gangsystematik der Parasitiformes. Teil 108. Tailgänge, Stadien von 8 neuen Trichouropoda-Arten. Acarologie. Schriftenreihe für Vergleichende Milbenkunde, 18, 11-15.

Hirschmann, W. \& Wiśniewski, J. (1986) Gangsystematik der Parasitiformes. Teil 491. Weltweite Revision der Ganggattung Trichouropoda Berlese, 1916. I. Die ovalis-Gruppe. (Trichouropodini, Uropodinae). Schriftenreihe für Vergleichende Milbenkunde, 33,1-81.

Hirschmann, W. \& Wiśniewski, J. (1987) Gangsystematik der Parasitiformes Teil 497. Weltweit Revision der Ganggatung Trichouropoda Berlese, 1916. I. die sociata-Gruppe (Trichouropodini, Uropodinae). Schriftenreihe für Vergleichende Milbenkunde, 34, 51-132.

Hirschmann, W. \& Zirngiebl-Nicol, I. (1961) Gangsystematik der Parasitiformes Teil 4. Die Gattung Trichouropoda Berlese, 1916 nov. comb., die Cheliceren und das System der Uropodiden. Schriftenreihe für Ver- 
gleichende Milbenkunde, 4, 1-34.

Karg, W. (1989) Acari (Acarina), Milben Unterordnung Parasitiformes (Anactinochaeta), Uropodina Kramer, Schildkrotenmilben. Die Tierwelt Deutschlands, 67, 1-203.

Khaustov, A.A., Klimov, P., Trach, V.A., Bobylev, A.N., Salavatulin, V.M., Khaustov, V.A. \& Tolstikov, A.V. (2018) Review of mites (Acari) associated with the european spruce bark beetle, Ips typographus (Coleoptera: Curculionidae: Scolytinae) in Asian Russia. Acarina, 26(1), 3-79.

http://doi.org/10.21684/0132-8077-2018-26-1-3-79

Khaustov, A.A., Trach, V.A. \& Bobylev, A.N. (2016) Mites (Acari) phoretic on six-toothed spruce bark beetle, Pityogenes chalcographus Linnaeus (Coleoptera: Curculionidae: Scolytinae), in Western Siberia, Russia. Acarina, 24, 137-151. http://doi.org/10.21684/0132-8077-2016-24-2-137-151

Kiełczewski, B. \& Wiśniewski, J. (1983) Bark beetle acarofauna in different types of forest habitat. I, II. Introduction and Mesostigmata. Folia Forestalia Polonica. Seria A. Leśnictwo, 25, 129-162.

Knee, W., Forbes, M.R. \& Beaulieu, F. (2013) Diversity and host use of mites (Acari: Mesostigmata, Oribatida) phoretic on bark beetles (Coleoptera: Scolytinae): Global generalists, local specialists? Annals of the Entomological Society of America, 106, 339-350.

http://doi.org/10.1603/AN12092

Koch, C.L. (1839) Übersicht des Arachnidensystems. Zweites Heft. C. H. Zehschen, Nürnberg, 38 pp.

Kontschán, J. (2009) First records of eleven Uropodina from Slovenia (Acari: Mesostigmata). Acta Entomologica Slovenica, 17(2), 107-114.

Kontschán, J. (2011) New Uropodina records from Switzerland (Acari: Mesostigmata) with the description of Discourella helvetica n. sp. Revue Suisse de Zoologie, 118(1), 99-106.

Kontschán, J. (2013) Uropodina mites of the Balkan Peninsula (Acari: Mesostigmata). Opuscula Zoologica Budapest, 44(suppl 1), 97-131.

Kontschán, J. (2014) Uropodina (Acari: Mesostigmata) of Transylvania (Romania). AdLibrum Kiadó, Budapest, $140 \mathrm{pp}$.

Kontschán, J. (2019) A new Trichouropodella species from bamboo bush and notes to Trichouropodellidae fam. nov. Systematic and Applied Acarology, 24(1), 96-105. http://doi.org/10.11158/saa.24.1.7

Kršlak, B., Zach, P. \& Kulfan, J. (2010) The role of Hylastes cunicularius Erichson (Coleoptera: Scolytidae) in transferring uropodine mites in a mountain spruce forest. Journal of Forest Science, 56, 258-264.

Lieutier, F., Mendel, Z. \& Faccoli, M. (2016) Bark beetles of Mediterranean conifers. In: Paine, T.D. \& Lieutier, F. (Eds), Insects and diseases of Mediterranean forest system. Switzerland, Springer International Publishing, pp. 105-197. http://doi.org/10.1007/978-3-319-24744-1_6

Moser, J.C. \& Bogenschütz, H. (1984) A key to the mites associated with flying Ips typographus in South Germany. Zeitschrift Fur Angewandte Entomologie-Journal of Applied Entomology, 97, 437-450.

Moser, J.C., Eidmann, H.H. \& Regnander, J.R. (1989) The mites associated with Ips typographus in Sweden. Annales Entomologici Fennici, 55, 23-27.

Moser, J.C., Konrad, H., Blomquist, S.R. \& Kirisits, T. (2010) Do mites phoretic on elm bark beetles contribute to the transmission of Dutch elm disease? Naturwissenschaften, 97(2), 219-27. http://doi.org/10.1007/s00114-009-0630-x.

Oudemans, A.C. (1915) Acarologische aanteekeningen. LVI. Entomologische Berichten, 4(83), 180-188.

Penttinen, R., Viiri, H. \& Moser, J.C. (2013) The mites (Acari) associated with bark beetles in the Koli National Park in Finland. Acarologia, 53, 3-15. http://doi.org/10.1051/acarologia/20132074

Takov, D., Pilarska, D. \& Moser, J. (2009) Phoretic mites associated with spruce bark beetle Ips typographus L. (Curculionidae: Scolytinae) from Bulgaria. Acta Zoologica Bulgarica, 61, $293-296$.

Vissa, S., Hofstetter, R.W., Bonifácio, L., Khaustov, A., Knee, W. \& Uhey, D.A. (2019) Phoretic mite communities associated with bark beetles in the maritime and stone pine forests of Setúbal, Portugal. Experimental and Applied Acarology, 77(2), 117-131. http://doi.org/10.1007/s10493-019-00348-6

Vitzthum, H.G. (1923) Acarologische Beobachtungen. 7. Reihe. Kommensalen der Ipiden. Archiv für Naturgeschichte, 89(2), 97-181.

Vitzthum, H.G. (1926) Acari als Commensalen von Ipiden. Zoologischer Jahrbücher (Jena), 52, 407-503. 
Vitzthum, H.G. (1943) Acarina. In: Bronns, H.G (ed.) Klassen und Ordnungen des Tierreichs. Band 5 Arthropoda, Abteilung IV Arachnoidea, Buch Acarina. Leipzig, Germany, Akademische Verlagsgescehllschaft, $1001 \mathrm{pp}$.

Vrabec, M., Kalúz, S. \& Ferenčík, J. (2012) Foretické roztoče na lykožrútovi smrekovom (Ips typographus) na vybraných lokalitách vo Vysokých Tatrách. Entomofauna Carpathica, 24, 1-14.

Wirth, S.F., Weis, O. \& Pernek, M. (2016) Comparasion of phoretic mites associated with bark beetles Ips typographus and Ips cembrae from Central Croatia. Šumarski list, 11-12, 549-560.

Wiśniewski, J. \& Hirschmann, W. (1984) Gangsystematik der Parasitiformes Teil 454. Teilgang einer neuen Trichouropoda-Art aus Borkenkäfergängen in Polen (Trichouropodini, Uropodinae). Schriftenreihe für Vergleichende Milbenkunde, 31,75-80.

Wiśniewski, J. \& Hirschmann, W. (1993) Gangsystematik der Parasitiformes Teil 548. Katalog der Ganggattungen, Untergattungen, Gruppen und Arten der Uropodiden der Erde. Acarologie. Schriftenreihe für Vergleichende Milbenkunde, 40, 1-220.

Zach, P., Kršiak, B., Kulfan, J., Parák, M. \& Kontschán, J. (2016) Mites Trichouropoda and Uroobovella spp. (Uropodoidea) phoretic on bark beetles (Scolytinae): a comparison from a declining mountain spruce forest in Central Europe. International Journal of Acarology, 42, 212-217.

http://doi.org/10.1080/01647954.2016.1154107

Submitted: 17 May 2019; accepted by Shahrooz Kazemi: 24 Jul. 2019; published: 6 Sep. 2019 